\title{
Editorial
}

\section{Welcome to Seminars in Thrombosis \& Hemostasis 2017 - New (2015) Impact Factor and Most Highly Cited Papers}

\author{
Emmanuel J. Favaloro, PhD, FFSc (RCPA) ${ }^{1}$ \\ ${ }^{1}$ Department of Haematology, Institute of Clinical Pathology and Medical \\ Research (ICPMR), Westmead Hospital, Westmead, New South Wales, \\ Australia
}

Semin Thromb Hemost 2017;43:1-3.

Welcome to the beginning of yet another year with Seminars in Thrombosis E Hemostasis (STH). This is my 9th year as Editorin-Chief, and my 12th year of editorial association with this journal, having originally served as a regional editor. First, as always, I wish to sincerely thank all the contributors to STH over past years, as well as the guest editors for these past issues, and of course the current and past senior and associate editors of the journal. There have been no new changes to the editorial team. We remain with four senior editors: Marcel Levi and Ton Lisman are European-based Senior Editors, and Hau Kwaan and Sam Schulman are North America-based Senior Editors. We also increased the ranks of associate editors last year, with the aim to have around 10 to 12 editors contributing from each of the "global regions" of America, Europe, and Asia Pacific. This set of editors will remain active in 2017.

\section{Seminars in Thrombosis \& Hemostasis}

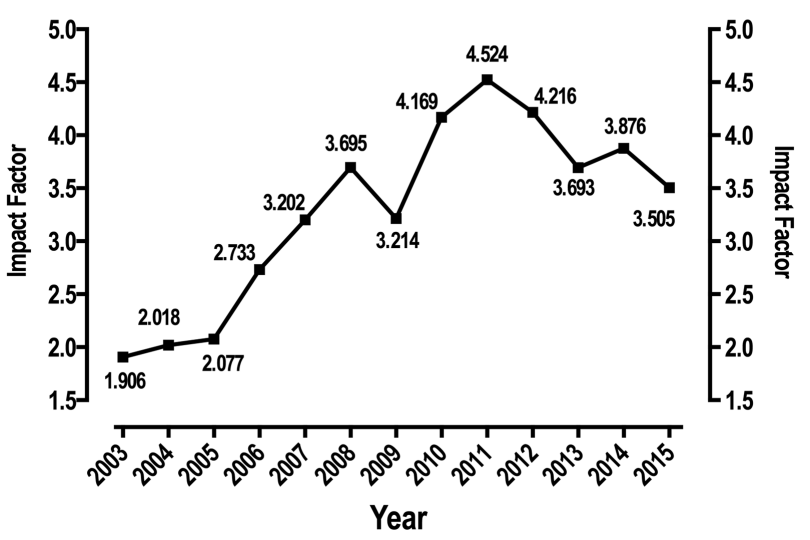

Fig. 1 The Impact Factor for Seminars in Thrombosis \& Hemostasis, from 2003 to 2015.

Address for correspondence Emmanuel J. Favaloro, PhD, FFSc (RCPA), Department of

Haematology, Centres for

Thrombosis and Haemostasis, Institute of Clinical Pathology and Medical Research (ICPMR),

Westmead Hospital, Westmead, NSW 2145, Australia (e-mail: emmanuel. favaloro@health.nsw.gov.au).
I will also take this opportunity to thank the journal production team at Thieme Medical Publishers for their high production standards and for facilitating both the print and online issues of the journal. In particular, I would like to thank Subhankar De, the project manager for STH, who manages the production process of STH issues and articles. I also wish to thank other key people at Thieme, who prefer to remain unnamed, for additional support provided over the recent years.

This is also the time that we reflect on our journal's Impact Factor, which for 2015 was 3.505, which represents a small fall from our 2014 Impact Factor of 3.876 (-Fig. 1). I am hopeful that this reflects a stabilization of the STH Impact Factor at around 4 over coming years. I also assessed the trends for Impact Factor changes for 2015 versus 2014 for STH in comparison with other thrombosis and hemostasis-

\section{IF change 2015-2014}

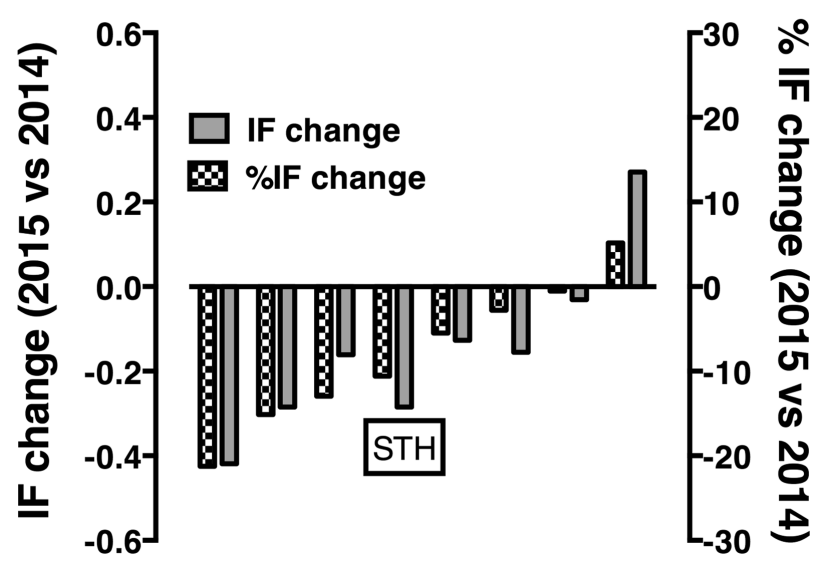

Fig. 2 Changes in the Impact Factor for Seminars in Thrombosis \& Hemostasis as well as other Thrombosis and Hemostasis focused journals from 2014 to 2015.

Copyright @ 2017 by Thieme Medical Publishers, Inc., 333 Seventh Avenue, New York, NY 10001, USA.

Tel: +1(212) 584-4662.
DOI http://dx.doi.org/ 10.1055/s-0036-1597291. ISSN 0094-6176.
Emmanuel ]. Favaloro, PhD, FFSc (RCPA), and Giuseppe Lippi, MD. 
Table 1 Top 20 papers cited in 2015, as published in 2013/2014

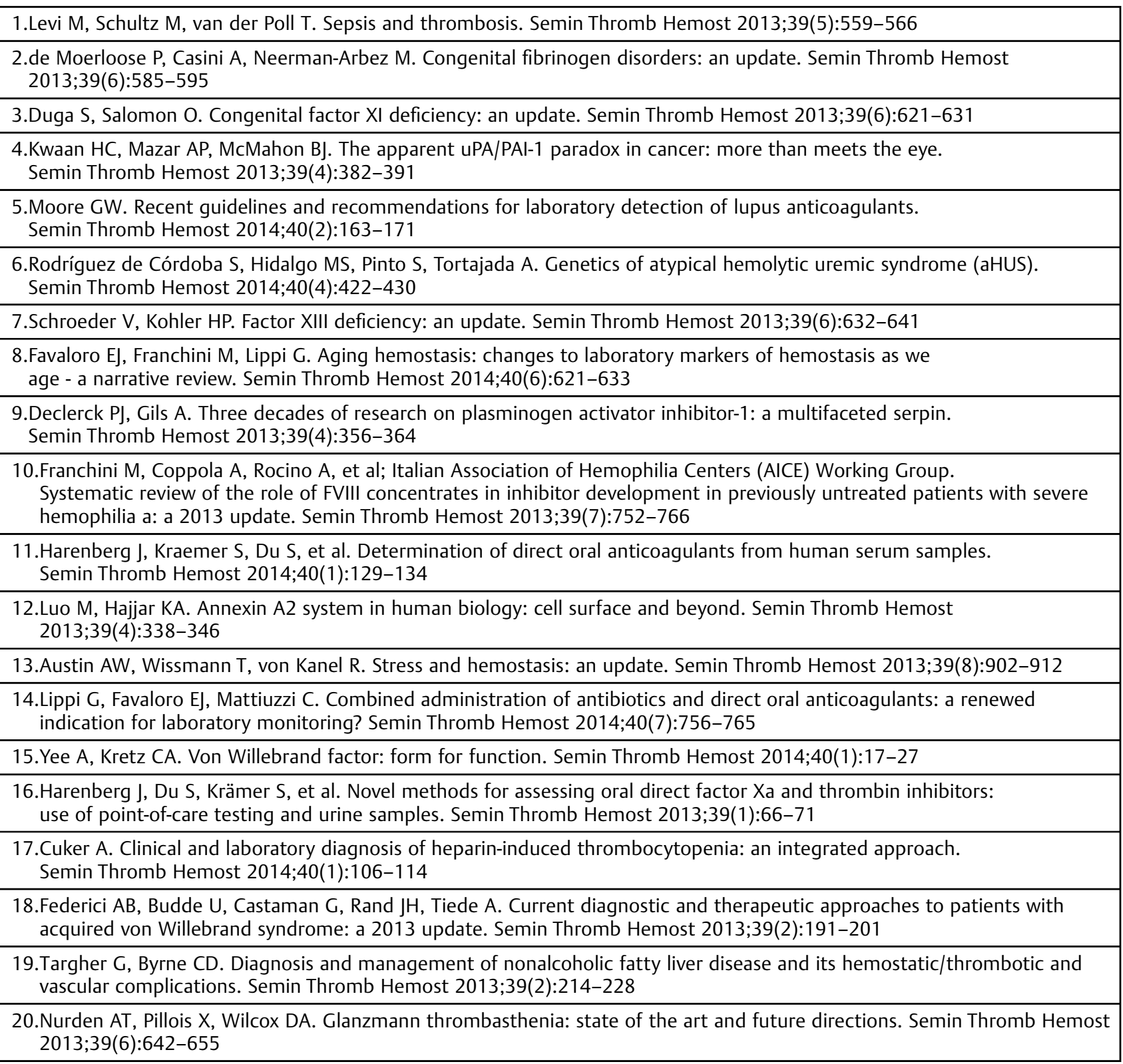

${ }^{\mathrm{a}}$ Thus contributing most to the 2015 Impact Factor.

focused journals, and these showed a generalized fall in all but a single journal (-Fig. 2). In any case, the Impact Factor is not the only marker of journal's "quality" that we should consider, given the existence of other biometric markers and the limitations of any individual marker (including the Impact Factor) as a "quality" indicator., ${ }^{1,2}$

As I also do annually now, the highest cited (2013/2014published) contributions ${ }^{3-22}$ from this journal are listed in -Table 1 for the potential interest of the readership and contributing authors. These contributions identify those publications most contributing to the 2015 Impact Factor, and each have now been cited eight or more times in literature. For those interested, the current listing can be compared with those of the most recently published top downloaded article listings from Seminars in Thrombosis $\mathcal{E}$
Hemostasis, the basis of the Eberhard F. Mammen "Most Popular" awards. ${ }^{23,24}$ Accordingly, I would like to thank all the contributors, guest editors, and the editorial team for bringing us the content that makes Seminars in Thrombosis $\mathcal{E}$ Hemostasis.

Finally, a short note to confirm that, as always, we will continue to develop plans for the future content of this journal, and we are confident that we will be able to continue to bring its readers the high-quality journal that is expected of us. Currently confirmed topics for issues that we plan to publish over the next 12 or so months are listed in -Table $\mathbf{2}$. At the same time, we recognize the need to retain some flexibility in our plans, and to potentially add additional material of current interest and controversy as the need arises. We look forward to another interesting year of reading in 2017. 
Table 2 Current planned topics for future issues of Seminars in Thrombosis \& Hemostasis

- Editorial compilations (continuing series)

- Thrombosis and hemostasis in surgery

- Laboratory assessment and monitoring of therapy in thrombosis and bleeding disorders

- Fibrinolysis

- Antiphospholipid antibodies and the antiphospholipid syndrome

- Recent advances in thrombosis and hemostasis (continuing series)

- Clinical scoring systems in thrombosis and hemostasis

- Point of care testing in acute hemorrhagic and thrombotic states

- Extrahemostatic functions of platelets/coagulation

\section{References}

1 Favaloro EJ. The Journal Impact Factor: don't expect its demise any time soon. Clin Chem Lab Med 2009;47(11):1319-1324

2 Favaloro EJ. Measuring the quality of journals and journal articles: the impact factor tells but a portion of the story. Semin Thromb Hemost 2008;34(1):7-25

3 Levi M, Schultz M, van der Poll T. Sepsis and thrombosis. Semin Thromb Hemost 2013;39(5):559-566

4 de Moerloose P, Casini A, Neerman-Arbez M. Congenital fibrinogen disorders: an update. Semin Thromb Hemost 2013;39(6): 585-595

5 Duga S, Salomon O. Congenital factor XI deficiency: an update. Semin Thromb Hemost 2013;39(6):621-631

6 Kwaan HC, Mazar AP, McMahon BJ. The apparent uPA/PAI-1 paradox in cancer: more than meets the eye. Semin Thromb Hemost 2013;39(4):382-391

7 Moore GW. Recent guidelines and recommendations for laboratory detection of lupus anticoagulants. Semin Thromb Hemost 2014;40(2):163-171

8 Rodríguez de Córdoba S, Hidalgo MS, Pinto S, Tortajada A. Genetics of atypical hemolytic uremic syndrome (aHUS). Semin Thromb Hemost 2014;40(4):422-430

9 Schroeder V, Kohler HP. Factor XIII deficiency: an update. Semin Thromb Hemost 2013;39(6):632-641
10 Favaloro EJ, Franchini M, Lippi G. Aging hemostasis: changes to laboratory markers of hemostasis as we age - a narrative review. Semin Thromb Hemost 2014;40(6):621-633

11 Declerck PJ, Gils A. Three decades of research on plasminogen activator inhibitor-1: a multifaceted serpin. Semin Thromb Hemost 2013;39(4):356-364

12 Franchini M, Coppola A, Rocino A, et al; Italian Association of Hemophilia Centers (AICE) Working Group. Systematic review of the role of FVIII concentrates in inhibitor development in previously untreated patients with severe hemophilia a: a 2013 update. Semin Thromb Hemost 2013;39(7):752-766

13 Harenberg J, Kraemer S, Du S, et al. Determination of direct oral anticoagulants from human serum samples. Semin Thromb Hemost 2014;40(1):129-134

14 Luo M, Hajjar KA. Annexin A2 system in human biology: cell surface and beyond. Semin Thromb Hemost 2013;39(4):338-346

15 Austin AW, Wissmann T, von Kanel R. Stress and hemostasis: an update. Semin Thromb Hemost 2013;39(8):902-912

16 Lippi G, Favaloro EJ, Mattiuzzi C. Combined administration of antibiotics and direct oral anticoagulants: a renewed indication for laboratory monitoring? Semin Thromb Hemost 2014;40(7): 756-765

17 Yee A, Kretz CA. Von Willebrand factor: form for function. Semin Thromb Hemost 2014;40(1):17-27

18 Harenberg J, Du S, Krämer S, et al. Novel methods for assessing oral direct factor Xa and thrombin inhibitors: use of point-of-care testing and urine samples. Semin Thromb Hemost 2013;39(1):66-71

19 Cuker A. Clinical and laboratory diagnosis of heparin-induced thrombocytopenia: an integrated approach. Semin Thromb Hemost 2014;40(1):106-114

20 Federici AB, Budde U, Castaman G, Rand JH, Tiede A. Current diagnostic and therapeutic approaches to patients with acquired von Willebrand syndrome: a 2013 update. Semin Thromb Hemost 2013;39(2):191-201

21 Targher G, Byrne CD. Diagnosis and management of nonalcoholic fatty liver disease and its hemostatic/thrombotic and vascular complications. Semin Thromb Hemost 2013;39(2):214-228

22 Nurden AT, Pillois X, Wilcox DA. Glanzmann thrombasthenia: state of the art and future directions. Semin Thromb Hemost 2013; 39(6):642-655

23 Favaloro EJ. 2015 Eberhard F. Mammen Award announcements: Part I-Most popular articles. Semin Thromb Hemost 2015;41(7): 673-679

24 Favaloro EJ. 2015 Eberhard F. Mammen Award announcements: Part II-Young investigator awards. Semin Thromb Hemost 2015; 41(8):809-815 